\title{
Evaluasi ketersediaan obat di beberapa puskesmas wilayah kabupaten $X$ tahun 2019
}

\author{
Andini Rezeki1, Bella Na Fhory ${ }^{1}$, Muhamad Saif Roies Yasa ${ }^{1}$, Syahriah ${ }^{1}$, Nashrul Wathan ${ }^{*}$ \\ ${ }^{1}$ Program Studi Profesi Apoteker, FMIPA, Universitas Lambung Mangkurat, Banjarbaru, Indonesia.
}

DOI: https://doi.org/10.29303/sjp.v2i2.120

Article Info

Submitted : $202107-11$

Revised : $202109-27$

Accepted : $202109-27$

\begin{abstract}
Drug management in public health centers (Puskesmas) needs to be solve properly to ensure continuing availability and affordability medical services that efficient, effective and rational. The aims of this study are to describe and evaluate drug management in four Puskesmas on Kabupaten $\mathrm{X}$, especially in planning, demanding, receiving, distribution, and storage. This study is a descriptive-evaluative study, with quantitative and qualitative methods, using retrospective data in 2019. The results show that suitability of the types of drugs available with the district drug formulary : 93.46-98.57\%; accuracy of drug demand $114-416 \%$; receiving accuracy $76-128 \%$; dead stock $1.3-31.57 \%$; prescriptioning generic drugs $94.72-100 \%$; and the value of damaged drugs $0-17,37 \%$. Results of this study can be concluded that the drug management in four Puskesmas should be further optimized because in 2019 not accordance with the standard.
\end{abstract}

Key words: Puskesmas, drug management, health agency formulary

Citation: Rezeki, A., Fhory, B. N., Yasa, M.S.R., Syahriah, Wathan, N. (2021). Evaluasi ketersediaan obat di beberapa puskesmas wilayah kabupaten $X$ tahun 2019. Sasambo Journal of Pharmacy, 2(2), 6572.https:// doi.org/10.29303/sjp.v2i2.120

\section{Pendahuluan}

Peningkatan kesejahteraan hidup masyarakat dalam bidang kesehatan merupakan salah satu dari sembilan agenda prioritas pemerintah (nawacita) untuk mencapai pembangunan berkelanjutan. Salah satu upaya pemerintah untuk meningkatkan kesehatan masyarakat yaitu dengan meningkatkan akses masyarakat terhadap fasilitas dan sarana kesehatan untuk menunjang suatu pelayanan kesehatan yang optimal dan salah satunya yaitu rumah sakit dan Puskesmas (Pratomo et al., 2018).

Puskesmas adalah unit pelaksana Teknis Dinas Kesehatan Kabupaten atau Kota yang bertanggung jawab menyelenggarakan pembangunan kesehatan di suatu wilayah kerja. Secara nasional standar wilayah kerja puskesmas adalah satu kecamatan. Apabila di satu kecamatan terdapat lebih dari satu puskesmas, maka tanggung jawab wilayah kerja dibagi antar puskesmas dengan memperhatikan kebutuhan konsep wilayah yaitu desa/kelurahan/dusun/rukun warga (RW) (Notoatmodjo, 1997).

Pelayanan kefarmasian merupakan kegiatan yang terpadu dengan tujuan untuk mengidentifikasi, mencegah dan menyelesaikan masalah obat serta masalah yang berhubungan dengan kesehatan (Menkes RI, 2016). Pengelolaan obat merupakan salah satu kegiatan pelayanan kefarmasian yang bersifat manajerial dengan memanfaatkan sumber-sumber yang tersedia (Fakhriadi et al., 2011). Pengelolaan obat meliputi tahap pemilihan, perencanaan kebutuhan, pengadaan, penerimaan, penyimpanan, pendistribusian, pemusnahan dan penarikan, pengendalian dan administrasi (Menkes RI, 2016). Tahapan-tahapan tersebut sangat menentukan ketersediaan obat. Jika ketersediaan obat tidak terpenuhi maka akan terjadi 
kekosongan obat yang akan mengakibatkan pelayanan kesehatan tidak optimal (Depkes RI, 2005). Ketersediaan obat harus disesuaikan dengan kebutuhan masyarakat untuk pelayanan pengobatan (Amiruddin, 2019).

Pengelolaan obat berhubungan erat dengan anggaran dan belanja instalasi kesehatan seperti rumah sakit, puskesmas, dan apotek. Biaya obat secara nasional sebesar 40\%-50\% dari jumlah oprasional pelayanan kesehatan (Satibi, 2014). Pengelolaan obat di puskesmas merupakan hal yang sangat penting yang perlu di perhatikan, mengingat dengan pengelolaan yang tidak sesuai dengan prosedur yang tepat akan terjadi masalah tumpang tindih anggaran dan pemakaian yang tidak tepat guna (Nurniati, 2016). Pelayanan puskesmas yang baik antara lain tergantung pada pengelolaan obat secara tepat dan benar. Berdasarkan hal tersebut maka perlu diteliti ketepatan mekanisme pengelolaan obat berdasarkan standar pengelolaan obat yang baik (Yohanes et al., 2015).

Perencanaan kebutuhan obat publik dan perbekalan kesehatan adalah salah satu fungsi yang menentukan dalam proses pengadaan obat publik dan perbekalan kesehatan. Dalam perencanaan kebutuhan buffer stok Pusat maupun Provinsi dengan menyesuaikan terhadap kebutuhan obat publik dan perbekalan kesehatan di Kabupaten/Kota dan tetap mengacu kepada DOEN 2019. Berbagai kegiatan yang dilakukan dalam perencanaan kebutuhan obat meliputi tahap pemilihan obat, tahap kompilasi dan tahap perhitungan kebutuhan obat.

Adapaun pendekatan perencanaan kebutuhan dapat dilakukan melalui beberapa metoda yaitu metoda konsumsi Didasarkan atas analisa data konsumsi obat tahun sebelumnya dan metoda morbiditas adalah perhitungan kebutuhan obat berdasarkan pola penyakit, perkiraan kenaikan kunjungan dan waktu tunggu (lead time) (Yohanes et al., 2015).

Penyimpanan adalah suatu kegiatan menyimpan dan memelihara dengan cara menempatkan obatobatan yang diterima pada tempat yang dinilai aman dari pencurian serta gangguan fisik yang dapat merusak mutu obat. Tujuan penyimpanan obat-obatan adalah untuk: memelihara mutu obat, menghindari penggunaan yang tidak bertanggung-jawab, menjaga kelangsungan persediaan, memudahkan pencarian dan pengawasan kegiatan penyimpanan obat meliputi pengaturan tata ruang, penyusunan stok obat, pencatatan stok obat dan pengamatan mutu obat (Kemenkes, 2010).

\section{Tujuan Penelitian}

Mendeskripsikan dan mengevaluasi sistem pengelolaan obat di puskesmas wilayah kabupaten $X$ dengan menggunakan indikator kesesuaian item obat yang tersedia dengan formularium Dinas Kabupaten X, ketepatan permintaan dan penerimaan obat, persentase obat yang tidak diresepkan selama 6 bulan, peresepan obat generik dan nilai obat rusak/kedaluarsa.

\section{Metode Penelitian}

\section{Jenis dan Rancangan Penelitian}

Penelitian ini termasuk dalam jenis penelitian deskriptif dan evaluatif secara non-eksperimen dengan pengambilan data retrospektif. Data dikumpulkan dan diambil dari Laporan Pemakaian dan Laporan Permintaan Obat (LPLPO), Rencana Kebutuhan Obat (RKO), dan Berita Acara Pemeriksaan Obat Rusak/Kedaluarsa/Hilang dari arsip tahun 2019 di empat puskesmas Kabupaten X, kemudian dianalisis secara kualitatif dan kuantitatif.

\section{Populasi dan Sampel}

Populasi yang digunakan yaitu seluruh item obat yang tersedia di empat puskesmas tersebut pada tahun 2019. Sampel yang digunakan yaitu lima obat dengan penggunaan terbanyak pada tahun 2019 yang memenuhi kriteria penelitian. Kriteria penelitian yang ditetapkan yaitu:

a) Kriteria Inklusi

1. Seluruh item obat generik dan obat penunjang.

2. Seluruh item obat yang rusak/kedaluarsa pada tahun 2019.

b) Kriteria Eksklusi

1. Alat Kesehatan, BMHP, reagen, vaksin dan perawatan gigi

2. Item obat yang kedaluwarsa di tahun sebelum ataupun sesudah 2019 yang diserahkan ke Gudang Farmasi Kabupaten pada tahun 2019.

\section{Analisis Data}

Data yang didapatkan dari hasil penelitian kemudian dihitung menggunakan rumus berikut:

(1) Persentase kesesuaian item obat yang tersedia di Puskesmas dengan Formularium Dinas Kabupaten X (a)

$\sum$ jenis obat yang termasuk

$\% \mathrm{a}=\frac{\text { ke dalam Formularium }}{\sum \text { jenis obat keseluruhan }} \times 100$ yang tersedia di PKM

(2) Persentase Ketepatan Permintaan obat di Puskesmas pada tahun 2019 (b)

$\% \mathrm{~b}=\frac{\sum \text { permintaan obat } \mathrm{X}+}{\sum \text { stok awal }} \times 10 \ldots$ 
(3) Persentase Ketepatan Penerimaan obat di Puskesmas pada tahun 2019 (c)

\% c $=\frac{\sum \text { penerimaan obat } \mathrm{X}}{\sum \text { permintaan obat } \mathrm{X}} \times 100$

(4) Persentase Obat yang Tidak Diresepkan Selama 6 Bulan di Puskesmas pada tahun 2019 (d)

$$
\% \mathrm{~d}=\frac{\begin{array}{c}
\sum \text { jenis obat yang stok pemakaiannya } \\
0 \text { selama } 6 \text { bulan berturut }- \text { turut }
\end{array}}{\sum \text { jenis obat keseluruhan }} \times 100 \ldots
$$

(5) Persentase Peresepan Obat Generik di Puskesmas pada tahun 2019 (e)

$\% \mathrm{e}=\frac{\sum \mathrm{R} / \text { Obat Generik }}{\sum \mathrm{R} / \text { Obat Keseluruhan }} x 100$

(6) Persentase obat rusak/ kadaluwarsa di Puskesmas pada tahun 2019 (f)

$\% \mathrm{f}=\frac{\sum \text { jenis obat yang rusak } / \text { kadaluwarsa }}{\sum \text { jenis obat keseluruhan }} \times 100$

\section{Hasil dan Pembahasan}

Kesesuaian Item Obat yang Tersedia dengan Formularium Dinas Kesehatan Kabupaten X

Kesesuaian item obat yang tersedia dengan Formularium Dinas Kesehatan Kabupaten X merupakan salah satu indikator yang digunakan unuk mengevaluasi perencanaan di Puskesmas. Perencanaan adalah suatu proses kegiatan seleksi obat untuk menentukan jumlah obat dalam rangka pemenuhan kebutuhan puskesmas (Menkes RI, 2016). Kegiatan perencanaan di puskesmas dilakukan dengan mengisi lembar Laporan Pemakaian dan Lembar Permintaan Obat (LPLPO). Pengelolaan obat di Puskesmas Kabupaten $X$ mengacu pada formularium yang dikeluarkan Dinas Kesehatan setempat. Formularium tersebut diharapkan dapat meningkatkan efisiensi pengadaan dan pengelolaan obat, karena formularium tersebut merupakan penerapan konsep obat esensial di Puskesmas yang berisi daftar obat terpilih dan informasi penggunaannya. Dasar pemilihan obat dilakukan berdasarkan pola penyakit yang berkembang di daerah, efisiensi, efektivitas, keamanan, kualitas, biaya, dan dapat dikelola oleh sumber daya dan keuangan Dinas Kesehatan Kabupaten X (Menkes RI, 2013).

Obat-obat yang termasuk ke dalam formularium adalah obat-obat esensial yang dibutuhkan untuk pelayanan kesehatan mencakup upaya diagnosis profilaksis, terapi dan rehabilitasi yang diupayakan tersedia di fasilitas kesehatan sesuai dengan fungsi dan tingkatnya. Pemilihan obat esensial telah mempertimbangkan manfaat dan resiko yang paling menguntungkan penderita, mutunya terjamin termasuk stabilitas dan bioavailabilitas, praktis dalam penyimpanan, pengangkutan, praktis dalam penggunaan, dan penyerahan disesuaikan dengan tenaga, sarana dan fasilitas kesehatan dan dari segi biaya cukup murah, disamping itu pemilihan obat esensial dapat meningkatkan akses serta kerasionalan obat (Menkes RI, 2013).

Kesesuaian jenis obat yang ada di Puskesmas dengan formularium dapat berpengaruh terhadap ketersediaan obat yang ada di Puskesmas tersebut, karena pengadaan obat oleh Dinas Kesehatan setempat dilakukan berdasarkan formularium tersebut. Persentase kesesuaian item obat yang tersedia di 4 puskesmas kabupaten $X$ dengan Formularium dapat dilihat pada Tabel 1.

Tabel 1. Kesesuaian Item Obat yang Tersedia dengan Formularium

\begin{tabular}{llll}
$\begin{array}{l}\text { Kode } \\
\text { Puskesmas }\end{array}$ & $\begin{array}{l}\sum \text { Jenis Obat } \\
\text { yang } \\
\text { Termasuk } \\
\text { dalam } \\
\text { Formularium } \\
\text { Kab. } \text { X }\end{array}$ & $\begin{array}{l}\sum \text { Jenis } \\
\text { obat } \\
\text { yang } \\
\text { tersedia } \\
\text { di PKM }\end{array}$ & $\begin{array}{l}\text { Persentase } \\
(\%)\end{array}$ \\
& 123 & 130 & 94,61 \\
\hline 1 & 138 & 140 & 98,57 \\
2 & 143 & 153 & 93,46 \\
4 & 184 & 190 & 96,84 \\
\hline
\end{tabular}

Sumber: data asli yang diolah

Hasil penelitian pada empat puskesmas di Kabupaten $X$ tidak $100 \%$ sesuai dengan formularium dinas Kabupaten tersebut. Akan tetapi, obat-obat yang tidak sesuai tersebut merupakan obat terpilih yang ada di Daftar Obat Esensial Nasional (DOEN) sehingga dapat disimpulkan bahwa perencanaan kebutuhan obat yang dilakukan oleh ke empat puskesmas tersebut tidak hanya berpedoman pada Formularium yang telah ditetapkan, tetapi juga berpedoman pada DOEN.

Kesesuaian obat yang tersedia di Puskesmas bila dibandingkan dengan DOEN menurut buku Materi Pelatihan Manajemen di Puskesmas yang disusun oleh Direktorat Bina Obat Publik dan Perbekalan Kesehatan, Direktorat Jenderal Bina Kefarmasian dan Alat Kesehatan, Kementrian Kesehatan Republik Indonesia yang bekerjasama dengan Japan International Cooperation Agency (JICA) tahun 2010 adalah 95\%. Hasil yang didapat dari penelitian ini menunjukkan bahwa hanya 2 diantara 4 puskesmas yang persentase nya tidak memenuhi standart yang ditetapkan yaitu kesesuaian dengan DOEN kurang dari 95\%. Penelitian serupa juga dilakukan oleh Saputra et al. (2021) dengan hasil 55,55\% dan Sulistyowati et al. (2020) dengan hasil $99,58 \%$. 
Obat-obat yang tidak termasuk formularium tetapi disediakan di puskesmas karena obat tersebut sering diresepkan oleh dokter dan dibutuhkan untuk pencegahan dan penyembuhan penyakit. Penggunaan obat diluar Formularium dapat dilakukan apabila sesuai indikasi medis dan pelayanan kedokteran setelah mendapat persetujuan dari Kepala Dinas Kesehatan Kab/Kota. Empat puskesmas di Kabupaten $\mathrm{X}$ menyediakan jenis obat yang sesuai dengan pola penyakit dan diseleksi berdasarkan Formularium Dinas Kabupaten setempat yang telah mempertimbangkan faktor drug of choice, analisis biaya manfaat, dan didukung dengan data klinis agar tercapai prinsip efektivitas dan efisiensi.

Masalah yang mungkin terjadi akibat tidak sesuainya perencanaan dengan Formularium Dinkes Kabupaten X yaitu persediaan obat yang kurang optimal. Dampak yang terjadi pada puskesmas yang ketersediaan obatnya kurang optimal yaitu tidak maksimal pelayanan obat pada pasien. Berdasarkan wawancara dengan petugas farmasi puskesmas menyatakan bahwa obat-obat yang tidak masuk dalam formularium tersebut sebenarnya telah dimasukkan ke dalam formularium dan sudah disepakati, tetapi ada kesalahan dalam penulisan formularium sehingga obat tersebut tidak ada dalam daftar di formularium. Oleh karena itu, hal yang perlu dilakukan yaitu merevisi formularium setiap satu tahun sekali sesuai perkembangan yang ada baik pola penyakit maupun kemajuan terapi dan pengobatan.

\section{Ketepatan Permintaan Obat}

Permintaan obat adalah kegiatan yang dilakukan oleh pengelola obat puskesmas yang bertujuan untuk memenuhi kebutuhan obat di masing-masing unit pelayanan kesehatan sesuai dengan pola penyakit yang ada di wilayah kerjanya (Chaira et al., 2016). Permintaan obat terbagi menjadi dua, yaitu permintaan rutin dan permintaan khusus. Permintaan rutin dilakukan sesuai dengan jadwal yang disusun oleh dinas Kesehatan kabupaten/kota untuk masingmasing puskesmas. Sedangkan permintaan khusus yaitu permintaan yang dilakukan diluar jadwal distribusi rutin, seperti pada saat kebutuhan meningkat dan penanganan Kejadian Luar Biasa (KLB) ) (Saputera, 2021).

Ketepatan permintaan kebutuhan obat puskesmas merupakan awal dari fungsi pengelolaan obat yang strategis. Indikator yang digunakan untuk mengevaluasi ketepatan permintaan obat yaitu jumlah obat yang diminta untuk satu periode distribusi ditambah dengan sisa stok bulan sebelumnya (stok awal) dibagi dengan total pemakaian obat perperiode (Saputera, 2021). Persentase ketepatan permintaan pada lima obat dengan penggunaan terbanyak dapat dilihat pada Tabel 2.

Tabel 2. Ketepatan Permintaan dan Penerimaan Obat pada 5 Obat Penggunaan Terbanyak di 4 Puskesmas tahun 2019

\begin{tabular}{|c|c|c|}
\hline Nama Obat & $\begin{array}{c}\text { Kode } \\
\text { Puskesmas }\end{array}$ & $\begin{array}{c}\text { Persentase } \\
\text { Ketepatan } \\
\text { Permintaan (\%) }\end{array}$ \\
\hline \multirow{4}{*}{$\begin{array}{l}\text { Amoksisilin } 500 \mathrm{mg} \\
\text { tablet }\end{array}$} & 1 & 281 \\
\hline & 2 & 199 \\
\hline & 3 & 174 \\
\hline & 4 & 178 \\
\hline \multirow{4}{*}{$\begin{array}{l}\text { Antasida } \\
\text { tablet }\end{array}$} & 1 & 415 \\
\hline & 2 & 214 \\
\hline & 3 & 210 \\
\hline & 4 & 172 \\
\hline \multirow{4}{*}{$\begin{array}{l}\text { Klorfeniramin } \\
\text { Maleat (CTM) } 4 \mathrm{mg} \\
\text { tablet }\end{array}$} & 1 & 416 \\
\hline & 2 & 304 \\
\hline & 3 & 261 \\
\hline & 4 & 246 \\
\hline \multirow{4}{*}{$\begin{array}{l}\text { Paracetamol } \\
\text { mg tablet }\end{array}$} & 1 & 213 \\
\hline & 2 & 114 \\
\hline & 3 & 231 \\
\hline & 4 & 179 \\
\hline \multirow[t]{4}{*}{ Vitamin B Komplek } & 1 & 310 \\
\hline & 2 & 260 \\
\hline & 3 & 226 \\
\hline & 4 & 184 \\
\hline
\end{tabular}

Sumber: data asli yang diolah

Hasil penelitian ini menunjukkan bahwa persentase ketepatan permintaan dari persentase terendah yaitu $114 \%$ dan persentase tertinggi yaitu $416 \%$. Standar ketepatan permintaan di Puskesmas menurut buku Materi Pelatihan Manajemen di Puskesmas yang disusun oleh Direktorat Bina Obat Publik dan Perbekalan Kesehatan, Direktorat Jenderal Bina Kefarmasian dan Alat Kesehatan, Kementrian Kesehatan Republik Indonesia yang bekerjasama dengan Japan International Cooperation Agency (JICA) tahun 2010 adalah 95\%. Sedangkan menurut Chaira et al. (2016) rentang ketepatan permintaan obat di puskesmas adalah 100-120 \%, dengan pertimbangan penambahan buffer stok adalah sebanyak $20 \%$. Dilihat dari hasil yang didapat hanya satu obat dari satu puskesmas yang memasuki rentang tersebut. Penelitian serupa juga dilakukan oleh Chaira et al. (2016) dengan hasil 2,28 - 24,47\%. Persentase yang didapat lebih tinggi dari $100 \%$, artinya permintaan yang dilakukan oleh puskesmas lebih banyak dibandingkan pemakaian sehingga puskesmas mengalami kelebihan stok obat. Hal ini dapat disebabkan oleh berbagai hal, salah satu diantaranya yaitu karena pola penyakit yang berubahubah setiap bulannya sehingga berpengaruh pada jumlah pemakaian obat. Selain itu juga dapat disebabkan oleh hal lain seperti antisipasi kekurangan 
ketersediaan obat karena obat yang diteliti merupakan obat fast moving.

Jumlah permintaan yang diajukan oleh puskesmas terkait kepada Dinas Kesehatan Kabupaten dibuat lebih besar dari pemakaian karena untuk menjaga persediaan obat di ruang farmasi puskesmas selalu tercukupi dan menghindari terjadinya kekosongan obat. Selain ruang farmasi puskesmas, permintaan yang dilakukan puskesmas juga bertujuan untuk memenuhi permintaan dari fasilitas kesehatan sub unit dibawahnya seperti Puskesmas Pembantu, Puskesmas Keliling, Posyandu Lansia ataupun Balita. Persediaan obat harus selalu ada karena untuk mengantisipasi adanya kejadian luar biasa (KLB) atau bencana alam yang mengakibatkan penggunaan obat juga meningkat.

\section{Ketepatan Penerimaan Obat}

Penerimaan adalah kegiatan yang dilakukan setelah melakukan permintaan. Hal yang dilakukan pada kegiatan ini yaitu menerima obat-obatan sesuai dengan apa yang telah diminta kepada Instalasi Farmasi terkait. Indikator yang digunakan untuk mengevaluasi kesesuaian penerimaan obat yaitu jumlah penerimaan dibagi dengan jumlah permintaan. Persentase ketepatan penerimaan pada lima obat dengan penggunaan terbanyak dapat dilihat pada Tabel 3.

Tabel 3. Ketepatan Penerimaan Obat pada 5 Obat Penggunaan Terbanyak di 4 Puskesmas tahun 2019

\begin{tabular}{lcc}
\hline \multicolumn{1}{c}{ Nama Obat } & $\begin{array}{c}\text { Kode } \\
\text { Puskesmas }\end{array}$ & $\begin{array}{c}\text { Persentase } \\
\text { Ketepatan } \\
\text { Penerimaan (\%) }\end{array}$ \\
\hline Amoksisilin 500 mg & 1 & 95 \\
tablet & 2 & 92 \\
& 3 & 117 \\
Antasida DOEN & 4 & 128 \\
tablet & 1 & 113 \\
& 2 & 93 \\
Klorfeniramin & 3 & 104 \\
Maleat (CTM) 4 mg & 4 & 100 \\
tablet & 1 & 100 \\
& 2 & 76 \\
\hline Paracetamol 500 & 3 & 92 \\
mg tablet & 4 & 90 \\
& 2 & 105 \\
& 3 & 118 \\
\hline Vitamin B Komplek & 4 & 112 \\
& 2 & 105 \\
\hline
\end{tabular}

Sumber: data asli yang diolah
Hasil ketepatan penerimaan dari persentase terendah yaitu $76 \%$ dan persentase tertinggi yaitu 128\%. Penelitian serupa dilakukan oleh Bambali (2019) dengan hasil yang didapatkan yaitu $81,18 \%$. Persentase melebihi $100 \%$ artinya pemberian dari Instalasi Farmasi terkait melebihi dari permintaan. Hal ini mungkin disebabkan oleh banyaknya stok di Instalasi Farmasi tersebut. Begitu pula sebaliknya, persentase dibawah $100 \%$ menunjukkan bahwa obat yang diterima kurang dari yang diminta. Hal ini dapat disebabkan oleh terbatasnya jumlah obat di Instalasi tersebut, sehingga untuk menjamin ketersediaan obat di puskesmas lainnya, instalasi farmasi membatasi pemberian untuk masing-masing puskesmas.

\section{Obat yang Tidak Diresepkan selama 6 bulan}

Obat yang tidak diresepkan selama 6 bulan atau bisa dikatakan stok mati merupakan salah satu indikator yang digunakan untuk mengevaluasi penggunaan obat. Persentase stok mati yang tinggi menunjukkan perputaran obat yang tidak lancar karena banyak persediaan obat yang tertahan dan menumpuk di gudang. Persentase obat yang tidak diresepkan dihitung dengan cara menghitung jumlah jenis obat yang stoknya tetap selama 6 bulan dibandingkan dengan jumlah jenis obat yang tersedia di puskesmas. Persentase obat yang tidak diresepkan selama 6 bulan dapat dilihat pada Tabel 4 .

Tabel 4. Obat yang Tidak Diresepkan selama 6 Bulan di 4 Puskesmas Kabupaten X tahun 2019

\begin{tabular}{cccc}
\hline $\begin{array}{c}\text { Kode } \\
\text { Puskesmas }\end{array}$ & $\begin{array}{c}\sum \text { Jenis Obat yang } \\
\text { tidak } \\
\text { Diresepkan } \\
\text { selama 6 Bulan }\end{array}$ & $\begin{array}{c}\sum \text { Jenis } \\
\text { obat yang } \\
\text { tersedia } \\
\text { di PKM }\end{array}$ & $\begin{array}{c}\text { Persentase } \\
\text { (\%) }\end{array}$ \\
\hline 1 & 31 & 130 & 23,85 \\
2 & 4 & 140 & 2,85 \\
3 & 2 & 153 & 1,30 \\
4 & 60 & 190 & 31,57 \\
\hline
\end{tabular}

Sumber: data asli yang diolah

Hasil penelitian ini menunjukkan bahwa obat yang tidak diresepkan selama 6 bulan dengan persentase terendah yaitu 1,3\% dan tertinggi 31,57\%. Penelitian Khairani et al. (2021) di dua puskesmas wilayah Magelang memperoleh persentase sebesar 40\% dan $20 \%$, sedangkan penelitian Kasmawati et al. (2018) memperoleh persentase sebesar $2,27 \%$. Standar yang ditetapkan untuk obat yang tidak diresepkan adalah 0\% (Direktorat Bina Obat Publik dan Perbekalan Kesehatan et al., 2010).

Indikator ini menunjukkan bahwa ada beberapa jenis obat yang tidak pernah terpakai dalam waktu 6 bulan, adanya jenis obat yang tidak terpakai ini dapat disebabkan oleh berbagai hal, misalnya 
peresepan yang tidak mengacu pada formularium (standar pengobatan) yang digunakan, kurangnya komunikasi antara pengelola obat dan pengguna obat (dokter) (Chaira et al., 2016), pengadaan obat yang tidak sesuai dengan kebutuhan dan terjadinya perubahan pola penyakit atau pola peresepan dokter (Dyahariesti \& Yuswantina, 2017). Banyaknya obat yang menumpuk di gudang tentunya akan menimbulkan kerugian karena meningkatnya resiko kerusakan obat dan obat yang kadaluwarsa.

Hasil wawancara dengan salah satu kepala gudang farmasi di Kabupaten X menyatakan bahwa adanya obat yang tidak diresepkan selama 6 bulan terjadi karena beberapa obat merupakan obat program dan obat emergensi. Obat program merupakan obat yang di kelola oleh penanggung jawab program, misalnya pelaksanaan program penanggulangan penyakit tertentu seperti kecacingan, malaria, gizi dan KIA (Kesehatan Ibu Anak). Obat ini hanya digunakan apabila program dilaksanakan. Selain obat program, obat yang tidak diresepkan selama 6 bulan yaitu obat emergensi seperti Dopamine injeksi, Ephedrin $\mathrm{HCl}$, Lidocain injeksi, Ventolin nebul, ISDN injeksi, Diazepam injeksi, dan Asam traneksamat injeksi. arena obat emergensi digunakan hanya saat ada pasien gawat darurat saja.

\section{Peresepan Obat Generik}

Peresepan obat generik merupakan indikator yang digunakan untuk mengevaluasi penggunaan obat selain indikator obat yang tidak diresepkan selama 6 bulan. Penggunaan obat generik menurut Direktorat Bina Obat Publik dan Perbekalan Kesehatan et al. (2010) merupakan suatu keharusan bagi sektor pelayanan kesehatan dasar milik pemerintah. Persentase peresepan obat generik dihitung dengan cara menghitung jumlah R/ (recipe) obat generik dibandingkan dengan jumlah R/ (recipe) secara keseluruhan. Persentase peresepan obat generik di empat Puskesmas dapat dilihat pada Tabel 5.

Tabel 5. Peresepan Obat Generik

\begin{tabular}{cccc}
\hline $\begin{array}{c}\text { Kode } \\
\text { Puskesmas }\end{array}$ & $\begin{array}{c}\sum \text { R/Obat } \\
\text { Generik }\end{array}$ & $\begin{array}{c}\sum \mathbf{R} / \\
\text { Keseluruhan }\end{array}$ & $\begin{array}{c}\text { Persentase } \\
\mathbf{( \% )}\end{array}$ \\
\hline 1 & 24129 & 25473 & 94,72 \\
2 & 52959 & 54402 & 97,34 \\
3 & 80435 & 80435 & 100 \\
4 & 41428 & 42883 & 96,61 \\
\hline
\end{tabular}

Sumber: data asli yang diolah

Hasil yang didapat dari penelitian ini diurutkan mulai dari terendah hingga tertinggi yaitu $94,72 \%$, 96,61\%, 97,34\%, dan 100\%. Dyaharesti \& Yuswantina (2017) juga melakukan penelitian serupa dengan persentase sebesar $41,8 \%$, sedangkan penelitian
Indriana et al. (2020) memperoleh persentase sebesar 93\%. Standar pelayanan minimal bidang kesehatan mengharuskan penulisan resep obat generik $100 \%$ di sarana pelayanan kesehatan milik pemerintah (Direktorat Bina Obat Publik dan Perbekalan Kesehatan et al., 2010). Oleh karena itu, dapat disimpulkan bahwa hanya satu puskesmas yang memenuhi standar. Berdasarkan wawancara dengan salah satu kepala gudang farmasi menyatakan alasan mengapa peresepan obat generik tidak dapat berjalan 100\% karena dari Dinas Kesehatan Kabupaten setempat mengadakan obat-obatan yang paten. Dinkes mengadakan obat-obat paten tersebut berdasarkan beberapa pertimbangan misalnya seperti adanya perbedaan harga yang signifikan antara obat generik dan obat generik bermerk atau tidak tersedianya obat generik saat itu.

\section{Nilai Obat Rusak/Kedaluarsa}

Nilai obat rusak/kedaluarsa merupakan indikator yang digunakan untuk mengevaluasi penyimpanan obat. Menurut Direktorat Bina Obat Publik dan Perbekalan Kesehatan et al. (2010), terjadinya obat rusak atau kadaluarsa dapat mencerminkan ketidaktepatan perencanaan, dan atau kurang baiknya sistem distribusi, dan atau kurangnya pengamatan mutu dalam penyimpanan obat dan atau perubahan pola penyakit. Persentase nilai obat rusak dihitung dengan cara menghitung jumlah jenis obat yang rusak/kedaluarsa dibandingkan dengan jumlah jenis obat yang tersedia di Puskesmas. Hasil yang diperoleh dilihat pada Tabel 6.

Tabel 6. Nilai Obat Rusak/Kedaluarsa

\begin{tabular}{ccccc}
$\begin{array}{c}\text { Kode } \\
\text { Puskes- } \\
\text { mas }\end{array}$ & $\begin{array}{c}\sum \text { Jenis } \\
\text { Obat } \\
\text { Rusak/ } \\
\text { Kadaluarsa }\end{array}$ & $\begin{array}{c}\sum \text { Jenis } \\
\text { obat } \\
\text { yang } \\
\text { tersedia } \\
\text { di PKM }\end{array}$ & $\begin{array}{c}\text { Persen- } \\
\text { tase } \\
(\%)\end{array}$ & $\begin{array}{l}\text { Nilai } \\
\text { (Rupiah) }\end{array}$ \\
\hline 1 & 15 & 130 & 11,54 & Rp. 3.048.978 \\
2 & 0 & 140 & 0 & - \\
3 & 25 & 153 & 16,33 & Rp. 9.278.038 \\
4 & 33 & 190 & 17,37 & Rp. 5.591.688 \\
\hline
\end{tabular}

Sumber: data asli yang diolah

Hasil yang didapat dari penelitian ini diurutkan mulai dari terendah hingga tertinggi yaitu $0 \%, 11,54 \%, 16,33 \%$, dan $17,37 \%$. Nilai standar untuk indikator persentase nilai obat kedaluarsa dan atau rusak menurut Pudjaningsih (1996) dalam Indriana et al. (2020) adalah sebesar $0-0,25 \%$, sehingga dapat disimpulkan bahwa dari ke empat puskesmas tersebut hanya satu puskesmas yang memenuhi nilai standar. Penelitian Khairani et al. (2021) di dua puskesmas wilayah Magelang memperoleh persentase sebesar 24\% dan $18 \%$, sedangkan penelitian Sulistyowati et al. (2020) 
memperoleh persentase sebesar 0,26\%. Menurut Auditable Pharmaceutical Transactions and Services (APTS) nilai kedaluarsa atau obat rusak untuk target normal nya adalah kurang dari 2\% (Ebrahim et al., 2019).

Obat yang telah mencapai tanggal kedaluarsa atau rusak dapat disebabkan oleh berbagai hal, seperti pengamatan mutu yang kurang dalam penyimpanan obat, tidak tepatnya permintaan obat, sistem distribusi yang kurang baik, dan terjadinya perubahan pola penyakit (Direktorat Bina Obat Publik dan Perbekalan Kesehatan et al., 2010). Hal lain yang mungkin dapat menyebabkan obat rusak yaitu tempat penyimpanan yang kurang memadai pada sub unit pelayanan kesehatan tersebut. Selain itu, kurangnya pengetahuan tenaga kesehatan (nakes) yang bertugas pada sub unit pelayanan kesehatan tersebut tentang tata cara penyimpanan obat yang baik juga mempengaruhi obat rusak/kedaluarsa.

Nilai obat rusak atau kedaluarsa juga berkaitan dengan pola penyimpanan obat. Penyimpanan obat yang baik perlu memperhatikan bentuk dan jenis sediaan, disusun berdasarkan FIFO (First In First Out) dan FEFO (First Expired First Out), memperhatikan kondisi yang dipersyaratkan dalam penandaan di kemasan obat, seperti suhu penyimpanan, cahaya, dan kelembaban, serta tidak menyimpan obat bercampur dengan barang lainnya karena dapat menyebabkan kontaminasi dan kerusakan fisik obat (Menkes RI, 2016).

Hal yang dilakukan untuk meminimalisir adanya obat yang rusak atau kadaluarsa yaitu perbekalan farmasi disusun dalam kemasan besar di atas pallet secara rapi dan teratur, menggunakan lemari khusus untuk penyimpanan narkotika dan psikotropika, menyimpan perbekalan farmasi yang dapat dipengaruhi oleh temperatur, udara cahaya dan kontaminasi bakteri pada tempat yang sesuai, menyimpan perbekalan farmasi dalam rak dan berikan nomor kode serta pemisahan obat dalam dan obat luar, mencantumkan nama masing-masing perbekalan farmasi pada rak dengan rapi, pemberian label LASA dan disimpan pada tempat yang jelas pembedaannya, terpisah atau diantarai dengan satu item obat yang lain, serta penyimpanan khusus untuk obat-obat yang perlu diwaspadai (high-alert medication) (Irnawati et al., 2016).

\section{Kesimpulan}

Evaluasi ketersediaan obat pada tahun 2019 di empat Puskesmas Kabupaten $X$ menggunakan 6 indikator dengan hasil : kesesesuaian item obat yang tersedia dengan Formularium Dinas Kesehatan Kabupaten X 93,46- 98,57\%; ketepatan permintaan obat
114-416\%; ketepatan penerimaan $76-128 \%$; obat yang tidak diresepkan selama 6 bulan 1,3-31,57\%, peresepan obat generik 94,72-100\%; dan nilai obat rusak 0-17,37\%. Dari hasil yang didapat maka dapat disimpulkan bahwa pengelolaan obat di empat puskesmas masih belum memenuhi standar yang ditetapkan.

\section{Ucapan Terima Kasih}

Tim penulis menyampaikan terimakasih yang sebesar-besarnya khususnya kepada Program Studi Profesi Apoteker FMIPA Universitas Lambung Mangkurat serta seluruh Pegawai Puskesmas Wilayah Kabupaten $\mathrm{X}$ yang turut berperan dalam proses pengambilan data.

\section{Daftar Pustaka}

Amiruddin, E. E \& W. I. Septarani. A. 2019. Studi Tentang Ketersediaan Obat di Puskesmas MeoMeo Kota Baubau. Jurnal Ilmiah Kesehatan. 1: 6076.

Bambali, T. A. 2019. Evaluasi Pengelolaan Obat dan Bahan Medis Habis Pakai di Puskesmas Oepoi Kota Kupang. Skripsi Program Sudi Sarjana Farmasi, Universitas Citra Bangsa, Kupang.

Chaira, S., E. Zaini \& T. Augia. 2016. Evaluasi Pengelolaan Obat pada Puskesmas di Kota Pariaman. Jurnal Sains Farmasi \& Klinis, 3: 35-41.

Depkes, RI. 2005. Pedoman Pengelolaan Obat Publik dan Perbekalan Kesehatan. Depkes RI, Jakarta.

Direktorat Bina Obat Publik \& Perbekalan Kesehatan., Direktorat Jenderal Bina Kefarmasian \& Alat Kesehatan., Kemenkes RI \& Japan International Cooperation Agency (JICA). 2010. Materi Pelatihan Menajemen Kefarmasian di Puskesmas. Kementrian Kesehatan Republik Indonesia, Jakarta.

Dyahariesti, N. \& R. Yuswantina. Evaluasi Keefektifan Penggelolaan Obat di Rumah Sakit. Media Farmasi Indonesia. 14 : 1485-1492.

Ebrahim, A. J., Teni, F. S. \& Yimenu, D. K. 2019. Unused and Expired Medication: Are They Threat? A Facility-Based Cross-Sectional Study. Journal of Primary Care \& Communiry Health. 10: 12311232. 
Fakhriadi, A., Marchaban dan P. Dwi. 2011. Analisis Pengelolaan Obat di Instalasi Farmasi Rumah Sakit Pku Muhammadiyah Temanggung Tahun 2006, 2007 dan 2008. Jurnal Manajemen dan Pelayanan Farmasi. 1: Universitas Gadjah Mada, Yogyakarta.

Herman, M. J., Rini, S. H. \& Yuyun, Y. 2009. Drug Management Reviews In District Drug Management Unit And General Hospital. Makara, Kesehatan. 13: 59-62.

Indriana, Y. M., E. S. Darmawan \& A. C. Sjaaf. 2020. Analisis Pengelolaan Obat di Instalasi Farmasi RSUA Tahun 2020. Jurnal Kesehatan Masyarakat. $11: 10-19$.

Irnawati, Sunarsih, \& R. Tosepu. 2016. Pengaruh Pendampingan Petugas Pengelolaan Obat Puskesmas Terhadap Perencanaan Obat dan Ketersediaan Obat di Kabupaten Kolaka. Jurnal Keperawatan dan Ksesehatan Masyarakat. 9: 1-12.

Kasmawati., Sabarudin \& S. A. Jamil. 2018. Evaluasi Ketersediaan Obat pada Era JKN-BPJS Kesehatan di RSUD Kota Kendari Tahun 2015. Jurnal Farmasi, Sains dan Kesehatan. 4: 59-62.

Kemenkes, RI. 2010. Materi Pelatihan Manajemen Kefarmasian di Puskesmas. Kemenkes Republik Indonesia, Jakarta.

Khairani, N. R., e. Latifah \& N. M. A. Septyaningrum. 2021.Evaluasi Obat Kadaluwarsa, Obat Rusak dan Stok Mati di Puskesmas Wilayah Magelang. Jurnal Farmasi Dan Ilmu Kefarmasian Indonesia. 8 : 91-97.

Menkes RI. 2013. Keputusan Menteri Kesehatan Republik Indonesia Nomor 312/Menkes/SK/IX/2013 tentang Daftar Obat Esensial Nasional 2013. Menteri Kesehatan Republik Indonesia, Jakarta.

Menkes RI. 2016. Peraturan Menteri Kesehatan Republik Indonesia Nomor 74 Tahun 2016 tentang Standar Pelayanan Kefarmasian di Puskesmas. Menteri Kesehatan Republik Indonesia, Jakarta.

Notoatmodjo, S. 1997. Pendidikan dan Perilaku Kesehatan dalam Ilmu Kesehatan Masyarakat. Jakarta, Rineka Cipta.

Nurniati, L., Hariati, L. \& Lisnawaty. 2016. Studi Tentang Pengelolaan Obat Di Puskesmas Buranga
Kabupaten Wakatobi Tahun 2016. Fakultas Kesehatan Masyarakat Universitas Halu Oleo.

Pratomo, G. S., A. Umaternate, \& T. Febriani. 2018. Evaluasi Ketersediaan Obat Instalasi Farmasi Rumah Sakit Islam PKU Muhammadiyah Palangkaraya. Borneo Journal of Pharmacy. 1: 5155.

Saputera, M. M. A., N. Y. Sari \& F. Jannah. 2021 Evaluasi Manajemen Pengelolaan Obat Tahap Selection dan Procurement Di Puskesmas Cempaka Putih Tahun 2018. Jurnal Insan Farmasi Indonesia. 4: 85-94

Satibi, W. 2014. Evaluasi Pengelolaan Obat Tahun 2005 di Dinas Kesehatan Kota X. Journal of Pharmaceutics Universitas Gajah Mada Yogyakarta. 6: 10-14.

Sulistyowati, W. D., A. Restyana \& A. W. Yuniar. 2020. Evaluasi Pengelolaan Obat Di Puskesmas Wilayah Kabupaten Jombang dan Faktor-Faktor yang Mempengaruhi. Jurnal Inovasi Farmasi Indonesia. $1:$ 60-75.

Yohanes, W. W., U. Athiyah, T. N. Rochmah. 2015. Analisis Faktor yang Mempengaruhi Pengelolaan Obat Publik di Instalasi Farmasi Kabupaten (Studi di Papua Wilayah Selatan). Jurnal Ilmu Kefarmasian Indonesia. 13: 94-101. 